\title{
REPRESENTASI PEMECAHAN MASALAH DESIMAL SISWA SD DITINJAU DARI GENDER
}

\author{
Susi Hermin Rusminati \\ Universitas PGRI Adi Buana Surabaya \\ susihermin@gmail.com
}

\begin{abstract}
Abstrak
Penelitian ini bertujuan untuk mendeskripsikan kemampuan siswa SD laki-laki dan perempuan saat mengerjakan soal desimal. Subjek dalam penelitian ini adalah siswa SD kelas V yang bertempat di SD Kemala Bhayangkari 9 Surabaya. Penelitian ini menggunakan pendekatan deskriptif kualitatif dengan kata lain peneliti menggali dan mengetahui informasi secara detail dengan mengumpulkan data melalui pemberian tes dan wawancara. Tes yang diberikan ada 3 tahap dengan waktu yang berbeda. Tes yang diberikan kepada siswa adalah sama. Dari hasil tes yang diberikan, menunjukkan bahwa siswa laki-laki saat mengerjakan operasi hitung desimal, siswa tersebut masih terlihat bingung dan mengerjakan dengan beberapa coretan yang ada dikertasnya. Dengan kata lain siswa laki-laki menggunakan representasi visual untuk menyelesaikan masalah, sedangkan siswa perempuan saat menyelesaikan masalah terlebih dahulu membaca kemudian menuangkan rencananya pada lembar jawaban, siswa tersebut langsung menuliskan rencananya tanpa menggunakan gambar. Hal ini dilakukan siswa tersebut karena dalam menyelesaikan soal tidak memerlukan gambar. Siswa langsung mengerjakan dan menghitung pecahan desimal tanpa menggunakan bantuan dengan menyamakan penyebutnya, kemudian menyelesaikan sesuai dengan permintaan pada soal.
\end{abstract}

Keywords: Representasi, Pemecahan Masalah, Gender

1.

\section{Pendahuluan}

Matematika menurut beberapa siswa adalah salah satu pelajaran yang dianggap sulit, bisa dikatakan bahwa matematika adalah momok. Hal ini dapat disebabkan karena kurang komunikatif antara guru dan siswa ketika proses belajar berlangsung. Dalam membelajarkan matematika seyogyanya guru bersikap komunikatif dengan mengajak siswa untuk aktif dan berperan dalam pembelajaran. Mengajak siswa untuk memecahkan masalah bersama dan sejenisnya. Dengan mengajak siswa untuk berperan serta maka siswa diajak pula untuk berpikir dan menuangkan ide-ide yang sudah ada dalam pikirannya.

Matematika merupakan pondasi segala ilmu, oleh karena itu sejak anak berusia Pra
TK perlu dibelajarkan matematika, seperti yang tercantum dalam National Council of Teachers of Mathematics (NCTM) bahwa program pembelajaran pra-taman kanakkanak (pra-TK) sampai kelas XII harus memungkinkan siswa untuk : (1) menciptakan dan menggunakan representasi untuk mengorganisir, mencatat, dan mengkomunikasikan ide-ide matematika; (2) memilih, menerapkan, dan menterjemahkan representasi matematika untuk pemecahan masalah; dan (3) menggunakan representasi untuk memodelkan dan menginterpretasikan fenomena fisik, sosial, dan matematika.

1. Pengertian Prepresentasi

Representasi adalah pengungkapan ideide matematika dengan menggunakan 
model seperti bahasa lisan, bahasa tulis, simbol, gambar, diagram, model, grafik, atau menggunakan anggota fisik dikatakan sebagai representasi ide (Goldin 1987). "Representation external ia acts of writing, speaking, manipulating the elements of same external concrete system, and so on..." (Goldin 2004), presentasi eksternal adalah aktifitas menulis, berbicara, memanipulasi sistem elemen-element nyata. Dapat dikatakan representasi eksternal adalah hasil dari perwujudan ide yang berupa tulisan, bahasa, gambar, tabel.

Berbicara tentang representasi matematika, dan pengungkapan ide-ide matematika perlu adanya perwujudan yang berupa representasi eksternal. Hubungan antara representasi internal dan eksternal sangat erat bahkan tidak dapat dipisahkan, hal ini dapat digambarkan seperti gambar berikut

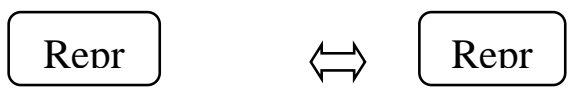

Hal ini dikarenakan representasi internal seseorang tidak dapat diamati secara kasat mata, karena representasi internalnya berupa ide-ide atau gagasan, untuk mengetahui apa yang ada dalam pikiran, maka seseorang tersebut dapat menuangkan ide-idenya dalam bentuk bahasa lisan, gambar, diagram, grafik, dan sebagainya, hal itulah yang dinamakan representasi eksternal. Oleh karena itu antara representasi internal dan representasi eksternal saling berkaitan bahkan tidak dapat dipisahkan.

Mudzakir (2006) telah menunjukkan indikator representasi matematika

\begin{tabular}{|l|l|}
\hline \multicolumn{1}{|c|}{ Representasi } & \multicolumn{2}{|c|}{ Indikator } \\
\hline Representasi & - Menyajikan \\
visual: & kembali \\
a. Diagram, & data/informasi \\
$\quad$ grafik, & dari suatu \\
atau tabel & representasi ke \\
\hline
\end{tabular}

\begin{tabular}{|c|c|}
\hline b. Gambar & $\begin{array}{l}\text { representasi } \\
\text { diagram, atau } \\
\text { tabel } \\
\text { menggunakan } \\
\text { representasi } \\
\text { visual untuk } \\
\text { menyelesaikan } \\
\text { masalah. } \\
\text { - Membuat } \\
\text { gambar untuk } \\
\text { memperjelas } \\
\text { masalah dan } \\
\text { memfasilitasi } \\
\text { penyelesaiannya. }\end{array}$ \\
\hline $\begin{array}{l}\text { Persamaan } \\
\text { atau ekspresi } \\
\text { matematik }\end{array}$ & $\begin{array}{l}\text { - } \text { Membuat } \\
\text { persamaan, } \\
\text { model } \\
\text { matematika atau } \\
\text { representasi dari } \\
\text { representasi lain } \\
\text { yang diberikan. } \\
\text { - Membuat } \\
\text { konjektur dari } \\
\text { suatu pola } \\
\text { hubungan. } \\
\text { - Menyelesaikan } \\
\text { masalah dengan } \\
\text { melibatkan } \\
\text { ekspresi } \\
\text { matematika. }\end{array}$ \\
\hline $\begin{array}{l}\text { Kata-kata atau } \\
\text { teks tertulis }\end{array}$ & $\begin{array}{l}\text { - Membuat situasi } \\
\text { masalah } \\
\text { berdasarkan data } \\
\text { atau masalah } \\
\text { representasi yang } \\
\text { diberikan. } \\
\text { - Menuliskan } \\
\text { interpretasi dari } \\
\text { suatu } \\
\text { representasi. } \\
\text { - Menuliskan } \\
\text { langkah-langkah } \\
\text { penyelesaian } \\
\text { masalah } \\
\text { matematika } \\
\text { dengan kata- } \\
\text { kata. } \\
\text { - Menyusun cerita } \\
\text { yang sesuai } \\
\text { dengan suatu }\end{array}$ \\
\hline
\end{tabular}


representasi yang disajikan.

- Menjawab soal dengan menggunakan kata-kata atau teks tertulis.

Indikator tersebut digunakan untuk mengukur representasi yang sudah dikemukakan oleh siswa berupa pemecahan masalah siswa SD yang berkaitan dengan desimal.

2. Pemecahan Masalah

"Solving a problem is finding the unknown means to a distinctly conceived end (Polya, 1973)" Memecahkan masalah adalah menemukan cara-cara tidak diketahui dan akhirnya dapat dipahami. Pemecahan masalah adalah suatu proses atau upaya individu untuk merespon atau mengatasi halangan atau kendala ketika suatu jawaban atau metode jawaban belum tampak jelas (Siswono 2008). Pemecahan masalah adalah usaha yang dilakukan seseorang untuk menyelesaikan masalah yang sedang dihadapi.

Ada 4 (empat) langkah pemecahan masalah menurut Polya, yaitu : (1) memahami masalah (understanding the problem); (2) membuat rencana penyelesaian (devising a plan); (3) melaksanakan rencana penyelesaian (carrying out the plan); dan (4) memeriksa kembali (looking back). Untuk menyelesaikan masalah, siswa dapat menggunakan 4 tahap menyelesaikan masalah menurut Polya. Disamping 4 tahap penyelesaian yang disampaikan Polya, ada pula 5 tahap proses pemecahan masalah yang dikemukakan oleh Krulik dan Rudnick (Siswono, 2008) yaitu (1) membaca dan memikirkan (read and think); (2) mengeksplorasi dan memecahkan (explore and plan); (3) memilih suatu strategi (select a strategy); (4) mencari suatu jawaban (find an answer); dan (5) merefleksi dan memperluas (reflect and extend). Proses pemecahan masalah yang digunakan peneliti yaitu langkahlangkah pemecahan masalah yang dikemukakan oleh Polya.

3. Hubungan Kemampuan Matematika dengan Representasi

"Empirical studies suggest that mathematics problem solving competency depend on one's ability to think in term of different representational system during problem solving process (Jones)" dapat diartikan studi empiris menunjukkan bahwa kompetensi pemacahan masalah matematika tergantung pada kemampuan seseorang untuk berpikir, dalam istilah sistem representasi yang berbeda selama proses pemecahan masalah.

Kemampuan matematika sangat diperlukan untuk merepresentasikan suatu wujud dari pemecahan masalah. Siswa yang memiliki kemampuan yang tinggi dapat merepresentasikan ide-ide yang ada dalam pikirannya. Oleh karena itu diperlukan kemampuan matematika yang tinggi agar siswa dapat merepresentasikan ide-ide atau gagasannya.

4. Gender

Perbedaan gender bukan hanya berakibat pada perbedaan kemampuan dalam matematika tetapi cara memperoleh pengetahuan matematika juga terkait dengan perbadaan gender (Sesento, 2006). "Gender, social, and cultural dimensions are very powerfully interacting in conceptualization of mathematics educations,..." (Bradon, 1985). Gender, sosial, dimensi-dimensi budaya memiliki interaksi yang sangat kuat dalam konsep pendidikan matematika. Akan tetapi tidak ada peran gender, laki-laki atau perempuan saling mengungguli dalam matematika bahkan perempuan bisa unggul dalam berbagai 
bidang yang berkaitan dengan matematika (Zhikia, 2003).

Ada beberapa anggapan bahwa adanya keterkaitan antara gender dan kemampuan dalam menyelesaikan masalah, begitu pula sebaliknya.

\section{Metode Penelitian}

Penelitian ini menggunakan pendekatan deskriptif kualitatif dengan subjek siswa SD. untuk menjaring subjek, peneliti memberikan tes untuk mengukur kemampuan matematika siswa, tes ini dinamakan tes kemampuan matematika yang kemudian disingkat dengan TKM. TKM ini diambil dengan memilih soal UASBN. Peneliti mengambil soal UASBN dikarenakan soal tersebut sudah memiliki standard an sudah di ujikan secara nasional, dari hasil tes yang diperoleh siswa, peneliti mengelompokkan subjek berdasarkan jenis kelamin. Kemudian peneliti melakukan langkah berikut

a. Memberikan instrument pemecahan masalah. Tes ini diberikan kepada siswa yaitu 2 siswa laki-laki dan 2 siswa perempuan, tes ini bertujuan untuk mengetahui representasi siswa dengan memperhatikan gender. Instrumen yang diberikan kepada siswa ini sudah di validasi oleh beberapa ahli di bidang matematika SD.

b. Wawancara.

Kegiatan wawancara juga dilakukan oleh peneliti kepada siswa yang sudah diberi tes pemecahan masalah. Wawancara ini dilakukan peneliti agar peneliti mengetahui secara detail langkah-langkah siswa dalam menyelesaikan tes. Instrumen wawancara ini juga divalidasi oleh ahli bahasa dan matematika.

Peneliti memberikan 3 kali tes yang sama dengan waktu yang berbeda.

\section{Hasil dan Pembahasan}

a. Representasi Siswa Laki-Laki dalam Menyelesaikan masalah desimal Dari hasil tes yang diberikan, dapat dijabarkan:
(1) pada tahap memahami masalah ini siswa langsung membaca soal berkali-kali dan menyebutkan informasi-informasi yang diterima

(2) siswa menggambarkan terlebih dahulu maksud soal yang sudah di baca.

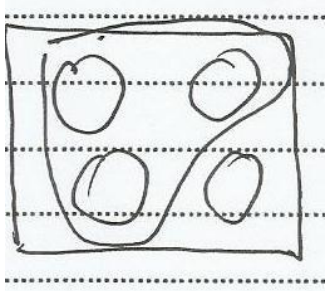

(3) pada tahap melaksanakan rencana Misalnya dari obat 4 tablet, yang di minum ayah ada 3 tablet sehari. Kemudian siswa menyamakan satuan menggunakan tangga satuan dan mengubah pecahan desimalnya.
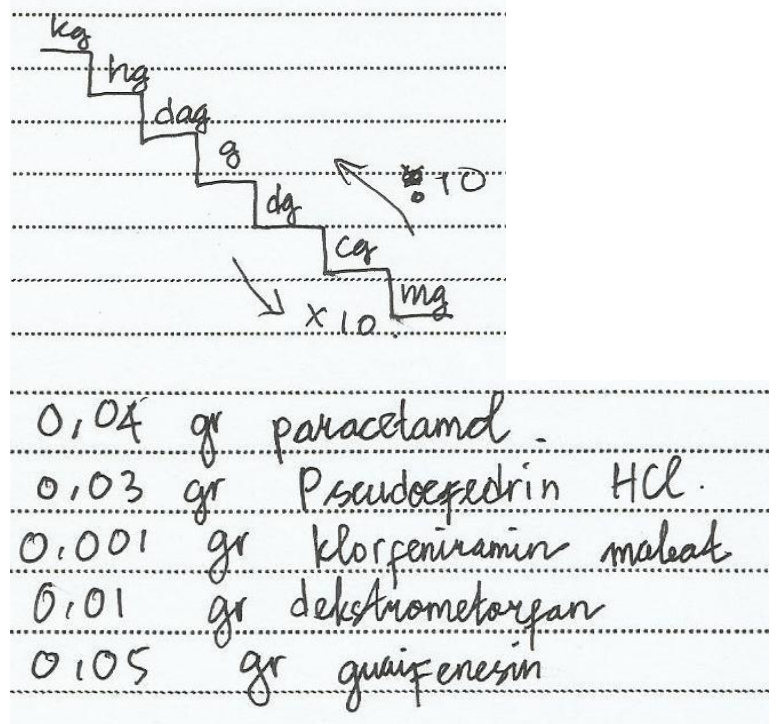

Setelah semua satuan sama, siswa menghitung sesuai dengan permintaan soal. (4) siswa melakukan pengecekan kembali hanya dengan membaca pekerjaannya.

b. Representasi Siswa Perempuan dalam Menyelesaikan masalah desimal

Dari hasil tes yang diberikan, dapat dijabarkan:

(1) pada tahap memahami masalah, siswa langsung membaca soal, siswa membaca soal 2 kali.

(2) pada tahap merencanakan masalah, siswa lebih teliti dan terlebih dahulu melihat satuan pada komposisi obat. 
0,04 gr paracetamol

$30 \mathrm{mg}$ pseudoefedrin $\mathrm{HCl}=0,03 \mathrm{gr}$

$1 \mathrm{mg}$ klorfeniramin maleat $=0,001 \mathrm{gr}$

0.01 gr dekskrometor Fan $\mathrm{HBr}$

0,05 gr guaifenesin

(3) pada tahap melaksanakan rencana, siswa mengerjakan soal seperti berikut

\begin{tabular}{|c|c|}
\hline $0,04 \times 3$ & \\
\hline $0,03 \times 3$ & \\
\hline $0,001 \times 3$ & \\
\hline $0,01 \times 3=$ & \\
\hline $0105 \times 3$ & \\
\hline 0,12 & \\
\hline 0,09 & \\
\hline $0,083 \mathrm{gr}$ & \\
\hline 0,03 & \\
\hline 0,15 & \\
\hline
\end{tabular}

siswa melakukan perkalian, kemudian menjumlahkan hasil dari perkalian tersebut.

(4) siswa melakukan pengecekan kembali dengan mengerjakan satu kali lagi sambil mengecek pekerjaannya.

Dari hasil tes yang diberikan dapat dilihat bahwa siswa perempuan menyelesaikan masalah dengan cara sistematis, mereka menggambarkan terlebih dahulu, kemudian menyelesaikan masalah dengan menyamakan penyebut dan menghitung desimal, lalu memberikan kesimpulan.

\section{Kesimpulan}

Siswa laki-laki lebih cenderung membaca soal dan menuliskan kembali informasi yang diterima pada soal yang di baca, kemudian mencari penyelesaiannya dengan menggunakan tangga satuan. Ketika mengerjakan operasi hitung desimal, siswa tersebut masih terlihat bingung dan mengerjakan dengan beberapa coretan yang ada dikertasnya. Dengan kata lain siswa laki-laki menggunakan representasi visual untuk menyelesaikan masalah.

Siswa perempuan ketika menyelesaikan masalah terlebih dahulu membaca kemudian menuangkan rencananya pada lembar jawaban, siswa tersebut langsung menuliskan rencananya tanpa menggunakan gambar. Hal ini dilakukan siswa tersebut karena dalam menyelesaikan soal tidak memerlukan gambar. Siswa langsung mengerjakan dan menghitung pecahan desimal tanpa menggunakan bantuan dengan menyamakan penyebutnya.

Terlihat bahwa ketika siswa menyelesaikan masalah, ada beberapa siswa yang harus memvisualisasikan informasi dan ide-idenya menggunakan gambar, ada pula yang memodelkannya dalam bentuk matematika. Semua itu bergantung pada kemampuan matematika yang dimiliki siswa. Siswa laki-laki maupun perempuan akan memiliki representasi yang baik jika siswa tersebut memiliki kemampuan matematika yang baik pula.

\section{Daftar Acuan}

Astar. 2014. Representasi Eksternal Siswa dalam Pemecahan Masalah Geometri Siswa SMP Ditinjau dari Kemampuan Matematika. Tesis. Surabaya: Program Pascasarjana (PPs) Universitas Negeri Surabaya.

Dagun, Save M. 1991. Maskulin dan Feminin : Perbedaan PriaWanita dalam Fisiologi, Psikologi, Seksual, Karier, dan MD. Jakarta ; Rineka Cipta.

Fakih, Dr. Mansour. 2008. Analisis Gender dan Transformasi Sosial. Yogyakarta: Pustaka Pelajar.

Goldin, G.A. (2004). A Joint Persperctive On The Idea Of Representastion In Learning And Doing Mathematics. Rutgers University

Goldin, G.A. (2002). Representation in Mathematical Learning and Problem Solving. In L.D English (Ed) International Research in Mathematical 
Education IRME, 197-218.

New Jersey. Lawrence Erlbaum Associates.

Jones \& Knut. 2005. Multiple Representation Skills And Creativity Effects On Mathematics Problem Solving Using A Multimedia Whiteboard System Educational Technology \& Society. National Central University: Taiwan.

Kartini. 2009. Peranan Representasi dalam Pembelajaran Matematika. Jogjakarta: Prosiding Seminar Pendidikan Matematika.

Manoy, Janet T. \& Luvia. Identifikasi Kemampuan Matematika Siswa dalam Memecahkan Masalah Aljabar di Kelas VIII Berdasarkan Taksonoi Solo.

ejournal.unesa.ac.idarticle2 36830article.pdf

Mudzakir. 2006. Representasi Belajar Berbasis Masalah. Jurnal Matematika atau pembelajarannya. ISSN: 085-7792. Tahun viii, Edisi Khusus.

National Council of Teacher Mathematic. (2000). Principles and Standars for Schools Mathematics. USA: Reston, V.A.

Rofiki, Imam. 2012. Profil Pemecahan Masalah Geometri siswa kelas akselerasi SMP Ditinjau dari Kemampuan Matematika dan Gender. Makalah Komprehensif. Surabaya: Program Pascasarjana (PPs) Universitas Negeri Surabaya.

Santia, Ika. 2014. Representasi Siswa SMA dalam Memecahkan Masalah Matematika Berdasarkan Gaya Kognitif.
Tesis. Surabaya: Program Pascasarjana (PPs) Universitas Negeri Surabaya.

Siswono, Tatag Y.E. 2008. Model Pembelajaran Matematika Berbasis Pengajuan dan Pemecahan Masalah untuk Meningkatkan Kemampuan Berpikir Kreatif. Surabaya: Unesa University Press.

Sugiyono. 2012. Memahami Penelitian Kualitatif. Bandung: CV. Alfabeta

Suherman, Erman. 2001. Strategi Pembelajaran Matematika Kontemporer. Bandung: JICA-UPI

Sukayasa. 2011. Karakteristik Penalaran Siswa SMP dalam Memecahkan Masalah Ditinjau dari Perbedaan Gender dan Tingkat Kemampuan Matematika. Disertasi tidak dipublikasikan. Surabaya: Program Pascasarjana (PPs) Universitas Negeri Surabaya.

Sumarno, U. 1994. Suatu Alternatif Pembelajaran Untuk Meningkatkan Kemampuan Problem Solving Matematika Pada Guru dan Siswa SMP. Laporan Hasil Penelitian. Bandung: Tidak Diterbitkan.

Utomo, Edi Setiyo. Profil Representasi Eksternal Siswa Tunagrahita ringan Dalam Pemecahan Masalah persegi dan Persegi Panjang. Tesis. Surabaya: Program Pascasarjana (PPs) Universitas Negeri Surabaya.

Van de Walle, John. 2007. Sekolah Dasar dan Menengah Matematika Pengembangan Pengajaran. Jakarta: Erlangga. 
Wiryanto. 2012. Representasi Siswa

Sekolah Dasar dalam Pemahaman Konsep

Pecahan. Jogjakarta: Prosiding Seminar

Pendidikan Matematika. 